\title{
Bioremoval of toxic Molybdenum using dialysis tubing
}

\author{
Mohd. Shukri Shukor ${ }^{1}$, Mohd. Yunus Shukor ${ }^{1,2}$ \\ ${ }^{\text {I}}$ Snoc International Sdn Bhd, Lot 343, Jalan 7/16 Kawasan Perindustrian Nilai 7, Inland Port, 71800, Negeri Sembilan, \\ Malaysia. ${ }^{2}$ Department of Biochemistry, Faculty of Biotechnology and Biomolecular Sciences, Universiti Putra Malaysia, \\ UPM 43400 Serdang, Selangor, Malaysia. Article Info: Submitted on March 20, 2015, Accepted on July 15, 2015.
}

\begin{abstract}
The toxicity of molybdenum to ruminants and its general toxicity to spermatogenesis in animals are increasingly being reported. Its contamination of aquatic bodies has been reported, and this necessitates its removal. In this work, we utilize the dialysis tubing method coupled with the molybdenum-reducing activity of $S$. marcescens strain Dr.Y6 to remove molybdenum from solution. The enzymatic reduction of molybdenum into the colloidal molybdenum blue traps the reduced product in the dialysis tubing. The initial rate of increase of Mo-blue product was determined using the modified Gompertz model while the resultant inhibition kinetics profile was carried out using the Haldane model. The calculated maximal rate of Mo-blue production was $153 \mu$ mole (Moblue.hr $)^{-1}$ and the concentration of molybdate resulting in the half-maximal rate of reduction $\left(K_{s}\right)$, and the inhibition constant $\left(K_{i}\right)$ were 0.22 and $506 \mathrm{mM}$, respectively. The results indicate that the system using dialysis tubing coupled with the Mo-reducing bacterium is a good candidate for a method for molybdenum bioremoval from solution.
\end{abstract}

Keywords: Molybdenum; Molybdenum blue; Gompertz; Dialysis tubing; S. marcescens.

\section{Introduction}

Molybdenum pollution has long been reported globally. ${ }^{1}$ It is relatively low in toxicity to human but it is known to be very toxic to ruminant animals causing scouring and deaths in cows at levels as low as 5 $\mathrm{ppm}^{2,3}$ In Tirol, Austria, the first case of bioremediation of molybdenum was attempted at a large pasture areas that was contaminated with high concentrations of molybdenum. ${ }^{4}$ In Malaysia, several cases of heavy metals pollution from a copper mine rich in minerals including molybdenum has been reported. High concentration of metals in the surrounding has been reported due to this episodic contamination. ${ }^{5,6}$ More recent reports on the toxicity of low concentration of molybdenum to spermatogenesis in animals and humans ${ }^{7-13}$ should be a warning signal to this potentially dangerous contaminant that have not been given a proper attention.

The use of bacteria in metal removal is a cost effective strategy. Enzymatic reduction of metals into less toxic precipitable states is the most often reported. ${ }^{14}$ In the case of molybdenum, its reduction to molybdenum blue (Mo-blue) is a striking example. The reduced product is colloidal and most often forms a precipitable mass with cellular biomass. ${ }^{15,16}$ Although microbial molybdate reduction has been reported since as early as $1896,{ }^{17}$ we are the only workers in the world since the last 15 years still working in microbial molybdenum reduction to Mo-blue $e^{18-44}$ as an efficient method of molybdenum bioremoval. We manage to purify the Mo-reducing enzyme ${ }^{45}$ and works on the elucidation of the mechanism through identification of the enzyme via sequencing is in underway. Previously, we report on the use of the dialysis tubing (membrane) to capture the reduced product using a strain of Moreducing bacterium. ${ }^{44}$ The idea was an extension of the works of Komori et al. $^{46}$ on the bioremoval of chromate using dialysis tubing.

The dialysis tubing method is a simple and cost effective bioremoval system as other systems such as reverse osmosis, membrane filtration, ion exchange and electrodialysis although more effective for removing metals ions, they are expensive and the pathway easily clogged. ${ }^{46,47}$ In this work we report on the use of another strain that was isolated from a contaminated site that showed a higher affinity towards molybdenum compared to the previous strain.

\section{Materials and Methods}

\section{Growth and maintenance of $S$. marcescens strain Dr.Y6}

Serratia marcescens strain Dr.Y6 was originally isolated from a contaminated site near the State Museum in the city of Taiping, State of Perak, Malaysia. The bacterium exhibits strong Mo-reducing capacity. ${ }^{21}$ The growth and maintenance of $S$. marcescens strain Dr.Y6 was maintained on a solid agar of low phosphate $(2.9 \mathrm{~m} M$ phosphate) media $(\mathrm{pH}$ 7.0) containing (\%w/v) sucrose (1.0), $\mathrm{MgSO}_{4} \cdot 7 \mathrm{H}_{2} \mathrm{O}$ 


\section{Chemical Engineering Research Bulletin 18(2015) 6-11}

(0.05), $\left(\mathrm{NH}_{4}\right)_{2} \mathrm{SO}_{4}(0.3)$, yeast extract $(0.05), \mathrm{NaCl}$ (0.5), $\mathrm{Na}_{2} \mathrm{HPO}_{4}(0.073)$ and $\mathrm{Na}_{2} \mathrm{MoO}_{4} \cdot 2 \mathrm{H}_{2} \mathrm{O}(0.726){ }^{23}$ The carbon source was autoclaved separately. For growth in liquid media $100 \mathrm{~m} M$ phosphate was used and this is called high phosphate media (HPM). For large-scale growth, $S$. marcescens strain Dr.Y6 was grown in $5 \mathrm{~L}$ of HPM at $30{ }^{\circ} \mathrm{C}$ for 48 hours on an orbital shaker at $100 \mathrm{rpm}$ (Kubota). The production of molybdenum blue from the media was measured at $865 \mathrm{~nm}$ using the specific extinction coefficient of 16.7 $\mathrm{mM}^{-1} \cdot \mathrm{cm}^{-1}$.

\section{Dialysis tubing experiment}

Cells were centrifuged for 10 minutes at 15,000 x g. The pellet was resuspended in low phosphate solution at $\mathrm{pH} 7.0$ containing (\%w/v) $\mathrm{MgSO}_{4} \cdot 7 \mathrm{H}_{2} \mathrm{O}(0.05)$, $\left(\mathrm{NH}_{4}\right)_{2} \mathrm{SO}_{4}(0.3), \mathrm{Na}_{2} \mathrm{HPO}_{4}(0.05), \mathrm{NaCl}(0.5)$ and yeast extract $(0.05){ }^{19}$ to an absorbance of 1.0 at 600 $\mathrm{nm}$. The cell density was about $0.0030 \mathrm{mg}$ dry cells $\mathrm{mL}^{-1}$. About $10 \mathrm{ml}$ of this suspension was transferred into a dialysis tubing that had been previously boiled for 10 minutes. The tubing was then immersed in 100 $\mathrm{ml}$ of sterile LPM media at $\mathrm{p}^{\mathrm{H}} 7.0$ containing various concentrations of sodium molybdate and incubated statically at $30{ }^{\circ} \mathrm{C}$. For the control, $10 \mathrm{ml}$ of the cell suspension was placed in a polypropylene tube and boiled for 10 minutes and cooled down and placed inside the dialysis tubing. Aliquots $(1 \mathrm{ml})$ of the media were periodically taken and then centrifuged for 15 minutes at $15,000 \mathrm{~g}$. The supernatant was read at 865 $\mathrm{nm}$. Experiments were carried out in triplicate.

\section{Modeling of Mo-blue production and kinetics}

Mo-blue production was modeled using the modified Gompertz model (eqn. 1) as this model is the most often used for microbial growth. ${ }^{48,49}$

$$
y=A \exp \left\{-\exp \left[\frac{\mu_{m} e}{A}(\lambda-t)+1\right]\right\}
$$

where $\mathrm{A}=$ Mo-blue production lower asymptote; $\mu_{m}=$ maximum specific Mo-blue production rate; $\mathrm{V}=$ affects near which asymptote maximum reduction occurs; $\lambda=$ lag time; $y_{\max }=$ Mo-blue production upper asymptote; $\mathrm{e}=$ exponent $(2.718281828) ; \mathrm{t}=$ sampling time.

Mo-blue rate of production that shows inhibition can be modelled using the Haldane inhibition model (eqn. 2) instead of the typical Monod kinetics. ${ }^{50}$ The model is as follows;

$$
q_{\max } \frac{S}{S+K_{s}+\frac{S^{2}}{K_{i}}}
$$

where $q_{\max }=$ maximal Mo-blue production rate $\left(\mathrm{h}^{-1}\right) ; K_{s}$ =half saturation constant for maximal Mo-blue production $(\mathrm{mM}) ; S=$ substrate concentration $(\mathrm{mM})$.

\section{Fitting of the data and statistical analysis}

The nonlinear equations were fitted to growth data by nonlinear regression with a Marquardt algorithm that minimizes sums of square of residuals using CurveExpert Professional software (Version 2.2). This is a search method to minimize the sum of the squares of the differences between the predicted and measured values. Values are reported as mean \pm standard deviation of three replicates. a Student's t-test or a oneway analysis of variance with post hoc analysis by Tukey's test was used for comparison between groups and $\mathrm{P}<0.05$ was considered statistically significant.

\section{Results and Discussion}

The increase in the production of Mo-blue inside of the dialysis tubing at different concentrations of sodium molybdate appears to be sigmoidal at all molybdate concentrations with observable lag periods of between 2 and 3.8 hours as molybdate concentration was increased to $70 \mathrm{mM}$ (Figs. 1 and 2). Mo-blue production was maximal at the eight hour and onwards for all concentrations of molybdenum tested. Previously, a linear increase of molybdenum blue production was observed in Serratia sp. strain DRY $5 .^{44}$ Molybdate at $20 \mathrm{mM}$ gave the highest level of molybdenum blue whilst the lowest was given by 70 $\mathrm{mM}$ (Fig. 1). Boiled cells showed no Mo-blue production (Data not shown). The initial rate of increase of Mo-blue product as obtained from the modified Gompertz model (Fig. 3) was plotted against molybdate concentration. This result in an inhibition kinetics profile (Fig. 3) that was modeled using the Haldane model. The calculated maximal rate of Moblue production was $153 \mu$ mole (Mo-blue.hr) ${ }^{-1}$ and the concentration of molybdate resulting in the halfmaximal rate of reduction $\left(K_{s}\right)$ and the inhibition constant $\left(K_{i}\right)$ were 0.22 and $506 \mathrm{mM}$, respectively. In comparison, the calculated maximal rate of Mo-blue production from Serratia sp. DRY5 was $264 \mu$ mole (Mo-blue.hr) ${ }^{-1}$ and the concentration of molybdate resulting in the half-maximal rate of reduction was $21.78 \pm 3.89 \mathrm{mM}$ molybdate. The very low $K_{s}$ value obtained in this work was about 100 times lower than Serratia sp. strain Dr.Y5 indicating the Mo-reducing activity in Serratia marcescens strain Dr.Y6 shows a stronger affinity towards molybdenum. The high cell density in the dialysis tube probably allows for maximal reduction in molybdate concentrations. The specific maximal rate of Mo-blue production was approximately $51.1 \mathrm{mmole}$ Mo-blue/hr/mg cells. In contrast, the specific maximal rate of Mo-blue 


\section{Chemical Engineering Research Bulletin 18(2015) 6-11}

production from Serratia sp. DRY5 is much higher at 80 mmole (Mo-blue.hr) $^{-1}$ per mg cells. ${ }^{44}$

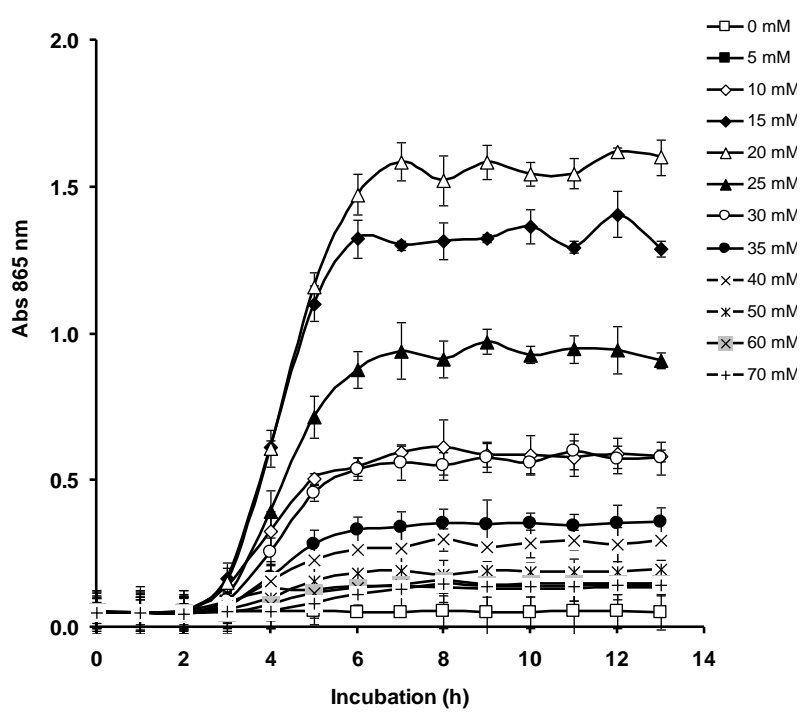

Figure 1: Mo-blue production in dialysis tubing by $S$. marcescens strain Dr.Y6 at various molybdenum concentrations. Error bars represent mean \pm standard deviation of three replicates.

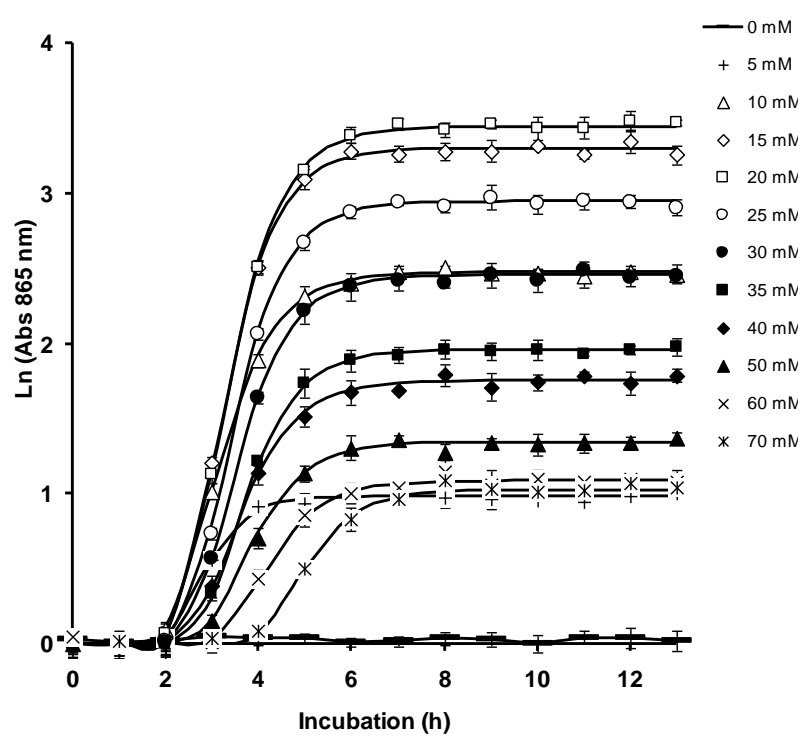

Figure 2: Mo-blue production in dialysis tubing by $S$. marcescens strain Dr.Y6 at various molybdenum concentrations fitted using the modified Gompertz model. Error bars represent mean \pm standard deviation of three replicates.

This high rate or Mo-blue production is not surprising since the most efficient Mo-reducing bacterium, $E$. cloacae strain 48 , could tolerate and reduce sodium molybdate at concentration as high as $200 \mathrm{mM} .^{16}$ For practical purposes, the highest concentrations of molybdate ever reported in soil or water bodies as a pollutant is approximately $2000 \mathrm{ppm}$ or $20.8 \mathrm{mM}^{51}$ Metal removal using similar strategy of membranous bacterial biofilm supported on PVC have been attempted for the removal of the toxic chromate with $72.6 \%$ removal rate achieved with an influent concentration of $200 \mu \mathrm{gL}^{-1} \mathrm{Cr}^{52}$. In another study, a chromate reducing bacterium using hydrogen gas as an electron donor, and immobilized in a membrane bioreactor was able to reduce chromium (vi) to chromium (ii) and insoluble precipitate removed. ${ }^{52}$

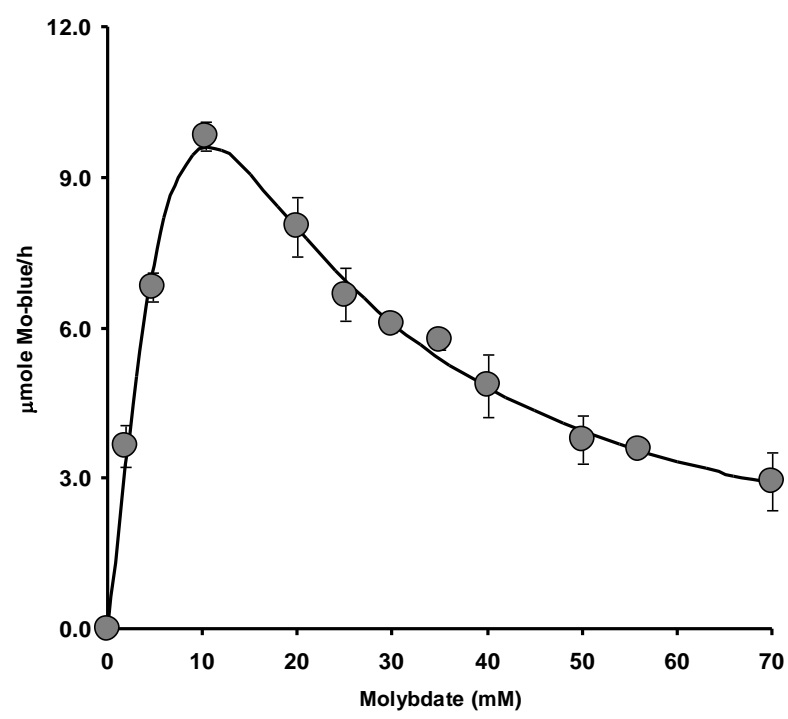

Figure 3: Rate of Mo-blue production at various molybdenum concentrations. Error bars represent mean \pm standard deviation of three replicates.

The Gompertz model is often used to model bacterial growth as the latter often shows a sigmoidal phase in which the specific growth rate starts at a value of zero followed by a lag time $(\lambda)$ before accelerating to a maximal value $(\mu \max )$ in a certain period of time. Then the final phase is where the rate decreases and eventually reaches zero otherwise known as the asymptote (A). The Gompertz model requires values of the bacterial growth, in this case molybdenum blue production, to be transformed using natural logarithm. ${ }^{49}$ To our knowledge, this is the first time the Gompertz model is used to model Mo-blue production from bacteria. Kong et al. ${ }^{47}$ use the modified Gompertz model to model the growth of bacterium in the presence of chromium during the latter's reduction.

The Haldane model has been cited for modelling the kinetics of metal-reducing bacterium such as mercury, ${ }^{53}$ arsenate $^{54}$ and chromate. $^{55}$ It is a modification to the Monod model, which in turn was inspired by the Michaelis-Menten enzyme kinetics model. ${ }^{50}$ The modification is necessary when substrate starts to inhibit the rate of product formation. 


\section{Chemical Engineering Research Bulletin 18(2015) 6-11}

\section{Conclusion}

In conclusion, the results indicated the resilience of this bacterium to high concentrations of molybdenum and its rapid reduction rate of this metal to the corresponding colloidal molybdenum blue. The reduction rate or Mo-blue production rate shows a sigmoidal pattern that could be efficiently modeled using the Gompertz model whilst the resultant inhibition kinetics can be efficiently modeled using the popular Haldane model. The very low concentration of molybdenum needed to achieve half maximal Mo-blue production rate in this bacterium was 100 times lower than a previous strain indicating a more efficient system in this bacterium. The fact that molybdenum is extremely toxic to other organisms means that the use of this bacterium in the removal of molybdenum, especially from aquatic bodies, is a very promising future. Hence, this novel technology in the case of molybdenum could be pursued further in dealing with actual water bodies or soils contaminated with molybdenum.

\section{Acknowledgement}

This project was supported by a fund from Snoc International Sdn Bhd.

\section{References}

1. G. K. Davis, "Molybdenum," E. Merian, ed. VCH Weinheim, New York, 1991, pp.1089-1100.

2. B. Sas, "Secondary copper deficiency in cattle caused by molybdenum contamination of fodder: A case history," Veterinary and Human Toxicology, vol.31, no. 1, pp.29-33, 1989.

3. N. N. Greenwood and A. Earnshaw, "Chemistry of the elements". Pergammon Press, Oxford, 1984.

4. C. Neunhäuserer, M. Berreck, and H. Insam, "Remediation of soils contaminated with molybdenum using soil amendments and phytoremediation," Water, Air, and Soil Pollution, vol.128, no. 1-2, pp.85-96, 2001.

5. H. Kosaka and K. Wakita, "Some geologic features of the Mamut porphyry copper deposit, Sabah, Malaysia," Economic Geology, vol.73, no. 5, pp.618-627, 1978.

6. F. S. Yong, "Mamut copper mine - The untold story," Minerals: Underpinning Yesterday's Needs, Today's Development and Tomorrow's Growth, Pacific Sutera Hotel, Kota Kinabalu, Saba, 2000.

7. C.-M. Bi, Y.-L. Zhang, F.-J. Liu, T.-Z. Zhou, Z.-J. Yang, S.-Y. Gao, S.-D. Wang, X.-L. Chen, X.-W. Zhai, X.-G. Ma, L.-J. Jin, and S. Wang, "The effect of molybdenum on the in vitro development of mouse preimplantation embryos," Systems Biology in Reproductive Medicine, vol.59, no. 2, pp.69-73, 2013.

8. R. C. Lewis and J. D. Meeker, "Biomarkers of exposure to molybdenum and other metals in relation to testosterone among men from the united states national health and nutrition examination survey 2011-2012.," Fertility and Sterility, Vol 103, no 1, pp. 172-178, 2015.

9. J. D. Meeker, M. G. Rossano, B. Protas, M. P. Diamond, E. Puscheck, D. Daly, N. Paneth, and J. J. Wirth, "Cadmium, lead, and other metals in relation to semen quality: Human evidence for molybdenum as a male reproductive toxicant," Environmental Health Perspectives, vol.116, no. 11, pp.1473-1479, 2008.

10. C. F. Mills, K. J. Monty, A. Ichihara, and P. B. Pearson, "Metabolic effects of molybdenum toxicity in the rat," The Journal of Nutrition, vol.65, no. 1, pp.129-142, 1958.

11. S. Yamaguchi, C. Miura, A. Ito, T. Agusa, H. Iwata, S. Tanabe, B. C. Tuyen, and T. Miura, "Effects of lead, molybdenum, rubidium, arsenic and organochlorines on spermatogenesis in fish: Monitoring at Mekong Delta area and in vitro experiment," Aquatic Toxicology, vol.83, no. 1, pp.43-51, 2007.

12. X.-W. Zhai, Y.-L. Zhang, Q. Qi, Y. Bai, X.-L. Chen, L.-J. Jin, X.-G. Ma, R.-Z. Shu, Z.-J. Yang, and F.-J. Liu, "Effects of molybdenum on sperm quality and testis oxidative stress," Systems Biology in Reproductive Medicine, vol.59, no. 5, pp.251-255, 2013.

13. Y.-L. Zhang, F.-J. Liu, X.-L. Chen, Z.-Q. Zhang, R.-Z. Shu, X.-L. Yu, X.-W. Zhai, L.-J. Jin, X.-G. Ma, Q. Qi, and Z.-J. Liu, "Dual effects of molybdenum on mouse oocyte quality and ovarian oxidative stress," Systems Biology in Reproductive Medicine, vol.59, no. 6, pp.312-318, 2013.

14. W. A. Ahmad, Z. A. Zakaria, A. R. Khasim, M. A. Alias, and S. M. H. S. Ismail, "Pilot-scale removal of chromium from industrial wastewater using the ChromeBac ${ }^{\mathrm{TM}}$ system," Bioresource Technology, vol.101, no. 12, pp.4371-4378, 2010.

15. A. M. Campbell, A. Del Campillo-Campbell, and D. B. Villaret, "Molybdate reduction by Escherichia coli K-12 and its chl mutants," Proceedings of the National Academy of Sciences of the United States of America, vol.82, no. 1, pp.227-231, 1985.

16. B. Ghani, M. Takai, N. Z. Hisham, N. Kishimoto, A. K. M. Ismail, T. Tano, and T. Sugio, "Isolation and characterization of a $\mathrm{Mo}^{6+}$-reducing bacterium," Applied and Environmental Microbiology, vol.59, no. 4, pp.1176-1180, 1993. 


\section{Chemical Engineering Research Bulletin 18(2015) 6-11}

17. A. Capaldi and B. Proskauer, "Beiträge zur Kenntniss der Säurebildung bei Typhus-bacillen und Bacterium coli - Eine differentialdiagnostische Studie," Zeitschrift für Hygiene und Infectionskrankheiten, vol.23, no. 3, pp.452-474, 1896.

18. M. Y. Shukor, N. A. Shamaan, M. A. Syed, C. H. Lee, and M. I. A. Karim, "Characterization and quantification of molybdenum blue production in Enterobacter cloacae strain 48 using 12molybdophosphate as the reference compound," Asia-Pacific Journal of Molecular Biology and Biotechnology, vol.8, no. 2, pp.167-172, 2000.

19. M. Y. Shukor, M. A. Syed, C. H. Lee, M. I. A. Karim, and N. A. Shamaan, "A method to distinguish between chemical and enzymatic reduction of molybdenum in Enterobacter cloacae strain 48," Malaysian Journal of Biochemistry, vol.7, pp.71-72, 2002.

20. Y. Shukor, H. Adam, K. Ithnin, I. Yunus, N. A. Shamaan, and A. Syed, "Molybdate reduction to molybdenum blue in microbe proceeds via a phosphomolybdate intermediate," Journal of Biological Science, vol.7, no. 8, pp.1448-1452, 2007.

21. M. Y. Shukor, S. H. M. Habib, M. F. A. Rahman, H. Jirangon, M. P. A. Abdullah, N. A. Shamaan, and M. A. Syed, "Hexavalent molybdenum reduction to molybdenum blue by $S$. marcescens strain Dr. Y6," Applied Biochemistry and Biotechnology, vol.149, no. 1, pp.33-43, 2008.

22. Y. Shukor, B. Shamsuddin, O. Mohamad, K. Ithnin, N. A. Shamaan, and M. A. Syed, "A method to study the effects of chemical and biological reduction of molybdate to molybdenum blue in bacteria," Pakistan Journal of Biological Science, vol.11, no. 4, pp.672-675, 2008.

23. M. F. A. Rahman, M. Y. Shukor, Z. Suhaili, S. Mustafa, N. A. Shamaan, and M. A. Syed, "Reduction of Mo(VI) by the bacterium Serratia sp. strain DRY5," Journal of Environmental Biology, vol.30, no. 1, pp.65-72, 2009.

24. M. Y. Shukor, M. F. Rahman, N. A. Shamaan, and M. S. Syed, "Reduction of molybdate to molybdenum blue by Enterobacter sp. strain Dr.Y13," Journal of Basic Microbiology, vol.49, no. SUPPL. 1, pp.S43-S54, 2009.

25. S. M. Yunus, H. M. Hamim, O. M. Anas, S. N. Aripin, and S. M. Arif, "Mo (VI) reduction to molybdenum blue by Serratia marcescens strain Dr. Y9," Polish Journal of Microbiology, vol.58, no. 2, pp.141-147, 2009.

26. M. Y. Shukor, M. F. Rahman, Z. Suhaili, N. A. Shamaan, and M. A. Syed, "Bacterial reduction of hexavalent molybdenum to molybdenum blue," World Journal of Microbiology and Biotechnology, vol.25, no. 7, pp.1225-1234, 2009.
27. M. Y. Shukor, S. A. Ahmad, M. M. M. Nadzir, M. P. Abdullah, N. A. Shamaan, and M. A. Syed, "Molybdate reduction by Pseudomonas sp. strain DRY2," Journal of Applied Microbiology, vol.108, no. 6, pp.2050-2058, 2010.

28. M. Y. Shukor, M. F. Rahman, Z. Suhaili, N. A. Shamaan, and M. A. Syed, "Hexavalent molybdenum reduction to Mo-blue by Acinetobacter calcoaceticus," Folia Microbiologica (Praha), vol.55, no. 2, pp.137-143, 2010.

29. H. K. Lim, M. A. Syed, and M. Y. Shukor, "Reduction of molybdate to molybdenum blue by Klebsiella sp. strain hkeem," Bulletin of Environmental Science and Management, vol.52, no. 3, pp.296-305, 2012.

30. L. K. A. Abo-Shakeer, S. A. Ahmad, M. Y. Shukor, N. A. Shamaan, and M. A. Syed, "Isolation and characterization of a molybdenumreducing Bacillus pumilus strain lbna," Bulletin of Environmental Science and Management, vol.1, no. 1, pp.9-14, 2013

31. S. A. Ahmad, M. I. E. Halmi, M. Y. Shukor, N. A. Shamaan, and M. A. Syed, "Effect of metal ions on the molybdenum-reducing activity of $S$. marcescens strain DrY6," Journal of Environmental Microbiology and Toxicology, vol.1, no. 1, pp.5-8, 2013.

32. M. I. E. Halmi, S. A. Ahmad, M. T. Yusof, M. Y. Shukor, and M. A. Syed, "Entrapment of Moreducing bacterium increase its resistance towards heavy metals," Bull. Environ. Sci. Manag., vol.1, no. 1, pp.11-13, 2013.

33. A. R. Othman, N. A. Bakar, M. I. E. Halmi, W. L. W. Johari, S. A. Ahmad, H. Jirangon, M. A. Syed, and M. Y. Shukor, "Kinetics of molybdenum reduction to molybdenum blue by Bacillus sp. strain A.rzi," BioMed Research International, vol.2013, no. Article ID 371058, p.9 pages, 2013.

34. M. A. Rahman, S. A. Ahmad, S. Salvam, M. I. E. Halmi, M. T. Yusof, M. Y. Shukor, N. A. Shamaan, and Syed, M.A., "Dialysis tubing experiment showed that molybdenum reduction in S. marcescens strain DrY6 is mediated by enzymatic action," Journal of Environmental Microbiology and Toxicology, vol.1, no. 1, pp.2527, 2013.

35. M. Y. Shukor, S. A. Raslan, K. Ithnin, N. A. Shamaan, and M. A. Syed, "An iron determination method for azo dyes-contaminated wastewater," Bulletin of Environmental Science and Management, vol.1, no. 1, pp.5-10, 2013.

36. S. A. Ahmad, M. I. E. Halmi, M. H. Wasoh, W. L. W. Johari, M. Y. Shukor, and M. A. Syed, "The development of a specific inhibitive enzyme assay for the heavy metal, lead," Journal of 


\section{Chemical Engineering Research Bulletin 18(2015) 6-11}

Environmental Microbiology and Toxicology, vol.1, no. 1, pp.9-13, 2013.

37. M. I. E. Halmi, W. L. W. Johari, S. Amir, R. Sulaiman, A. Azlina, M. Y. Shukor, and Syed, M.A., "Monitoring of heavy metals level in fish using the Microtox ${ }^{\circledR}$ assay," Bioremediation Science and Technology Research, vol.1, no. 1, pp. 19-22, 2013.

38. S. A. Ahmad, M. Y. Shukor, N. A. Shamaan, W. P. Mac Cormack, and M. A. Syed, "Molybdate reduction to molybdenum blue by an Antarctic bacterium," BioMed Research International, vol.2013, no. Article ID 871941, p.10 pages, 2013.

39. M. I. E. Halmi, S. W. Zuhainis, M. T. Yusof, N. A. Shaharuddin, W. Helmi, Y. Shukor, M. A. Syed, and S. A. Ahmad, "Hexavalent molybdenum reduction to Mo-blue by a Sodium-DodecylSulfate-degrading Klebsiella oxytoca strain DRY14," BioMed Research International, vol.2013, p.e384541, 2013.

40. M. I. E. Halmi, S. A. Ahmad, M. A. Syed, N. A. Shamaan, and M. Y. Shukor, "Mathematical modelling of the molybdenum reduction kinetics in Bacillus pumilus strain Lbna," Bulletin of Environmental Science and Management, vol.2, no. 1, pp.24-29, 2014.

41. M. I. E. Halmi, "Chemistry, biochemistry, toxicity and pollution of molybdenum: a mini review," Journal of Environmental Microbiology and Toxicology, vol.2, no. 1, pp.1-6, 2014.

42. A. Khan, M. I. E. Halmi, and M. Y. Shukor, "Isolation of Mo-reducing bacterium in soils from Pakistan," Journal of Environmental Microbiology and Toxicology, vol.2, no. 1, pp.38-41, 2014.

43. A. R. Othman, S. A. Ahmad, B. Gunasekaran, M. I. E. Halmi, N. A. Shamaan, M. A. Syed, and M. Y. Shukor, "River monitoring of mercury using a novel molybdenum-reducing enzyme assay," Bulletin of Environmental Science and Management, vol.2, no. 1, pp.30-35, 2014.

44. M. I. E. Halmi, H. Wasoh, S. Sukor, S. A. Ahmad, M. T. Yusof, and M. Y. Shukor, "Bioremoval of molybdenum from aqueous solution," International Journal of Agriculture and Biology, vol.16, no. 4, pp.848-850, 2014.

45. M. Y. Shukor, M. I. E. Halmi, M. F. A. Rahman, N. A. Shamaan, and M. A. Syed, "Molybdenum reduction to molybdenum blue in Serratia sp. strain DRY5 is catalyzed by a novel molybdenumreducing enzyme," BioMed Research International, vol.2014, no. Article ID 853084, p.8 pages, 2014.
46. K. Komori, A. Rivas, K. Toda, and H. Ohtake, "A method for removal of toxic chromium using dialysis-sac cultures of a chromate-reducing strain of Enterobacter cloacae," Applied Microbiology and Biotechnology, vol.33, no. 1, pp.117-119, 1990.

47. B. Kong, X. Zeng, X. Liu, X. Li, J. Li, S. Luo, and W. Wei, "Kinetic study and mathematical modeling of chromium(VI) reduction and microorganism growth under mixed culture," Current Microbiology, vol.59, no. 5, pp.565-571, 2009.

48. B. Gompertz, "On the nature of the function expressive of the law of human mortality, and on a new mode of determining the value of life contingencies," Philosophical Transactions of the Royal Society of London, vol.115, pp.513-585, 1825.

49. M. H. Zwietering, I. Jongenburger, F. M. Rombouts, and K. Van't Riet, "Modeling of the bacterial growth curve," Applied and Environmental Microbiology, vol.56, no. 6, pp.1875-1881, 1990.

50. B. Boon and H. Laudelout, "Kinetics of nitrite oxidation by Nitrobacter winogradskyi," The Biochemical Journal, vol.85, pp.440-447, 1962.

51. D. D. Runnells, D. S. Kaback, and E. M. Thurman, "Geochemistry and sampling of molybdenum in sediments, soils, and plants in Colorado," in Molybdenum in the environment, W. R. Chappel and K. K. Peterson, eds. Marcel and Dekker, Inc., New York, 1976.

52. Y. Zhang, J. Liu, K. Zhang, L. Xing, and S. Xia, "Studies on chromate reduction by a polyvinyl chloride hollow fiber membrane biofilm reactor," Fresenius Environmental Bulletin, vol.20, no. 6 A, pp.1541-1546, 2011.

53. P. Gluszcz, J. Petera, and S. Ledakowicz, "Mathematical modeling of the integrated process of mercury bioremediation in the industrial bioreactor," Bioprocess and Biosystems Engineering, vol.34, no. 3, pp.275-285, 2011.

54. S. O. Soda, S. Yamamura, H. Zhou, M. Ike, and M. Fujita, "Reduction kinetics of As (V) to As (III) by a dissimilatory arsenate-reducing bacterium, Bacillus sp. SF-1," Biotechnology and Bioengineering, vol.93, no. 4, pp.812-815, 2006.

55. M. Sukumar, "Reduction of hexavalent chromium by Rhizopus oryzae," African Journal of Environmental Science and Technology, vol.4, no. 7, pp.412-418, 2010.

\section{Available online at http://www.banglajol.info/index.php/CERB}

Publisher: Department of Chemical Engineering, Bangladesh University of Engineering and Technology (BUET). Review \&Publication: A submitted original manuscript is taken into review only if the uniqueness is found to be more than $85 \%$ in plag-scanning and selected for publication by the complete acceptance from at least two reviewers out of three. Home Page: http://www.banglajol.info/index.php/CERB . Indexed by Chemical Abstract Service (CAS), CEABA-VtB, Google Scholar, Scopus and DOAJ 